\title{
Małe formy, wielkie sprawy. Deontologia a potoczność w przekazach audiowizualnych dostępnych na YouTube
}

\section{Images}

vol. X/no. 19

Poznań 2012

ISSN 1731-45OX

\author{
YouTube is a place to discover, \\ watch, \\ upload \\ and share videos.
}

Użytkownik Internetu - wraz z pojawieniem się serwisu You-

Wprowadzenie Tube - znalazł dla siebie medium służące do wyrażania własnych opinii, radości, tęsknot i lęków oraz do poznawania wrażliwości, zainteresowań czy cierpienia innych osób.

Społeczne znaczenie tego serwisu powstaje na styku wielkich spraw, o których można mówić, wykorzystując małe formy przekazu. YouTube jest wyzwaniem dla medioznawców, psychologów, teoretyków tekstu oraz filmoznawców. Wynika to z problemów gatunkowych, stylistycznych oraz ideologicznych, w które uwikłani są użytkownicy i tworzone przez nich audiowizualne przekazy. Dla dowolnie sformułowanej przez użytkownika frazy serwis YouTube wyświetla podpowiedzi, które będą się różniły między sobą gatunkowo, merytorycznie, stylistycznie. Dla zapytania o „Holokaust” będzie można uzyskać odpowiedzi, wśród których znajdą się fragmenty filmów fabularnych, dokumentalnych, prezentacje multimedialne czy amatorskie przekazy tworzone w poetyce pastiszu, które arbitralnie i dowolnie odnoszą się do wydarzenia „opisanego" przez to pojęcie.

Z możliwości mówienia o wielkich sprawach przy wykorzystaniu małych form wynika, że wielkie sprawy stają się treścią doświadczeń potocznych. Dotyczy to tak złożonych zagadnień, jak Holokaust[1], II wojna światowa[2], ludobójstwo w Rwandzie[3], zamach na World Trade Center $\left.{ }^{4}\right]$ czy katastrofa smoleńska[5] (zestawienie

[1] Liczba dostępnych na YouTube materiałów odnoszących się do słowa „Holokaust” wynosi 1230 rekordów, natomiast słowo „Holocaust” łączy się w tym serwisie z ponad 132000 przekazów [dostęp: 29.11.2011]. [2] Liczba dostępnych na YouTube materiałów odnoszących się do frazy „II wojna światowa” wynosi 3130 rekordów, natomiast fraza $\mathrm{w}$ języku angielskim „World War II" łączy się w tym serwisie z ponad 180000 przekazów [dostęp: 29.11.2011].

[3] Liczba dostępnych na YouTube materiałów odnoszących się do frazy „ludobójstwo w Rwandzie” wynosi 11 rekordów, natomiast fraza w języku angiel- skim „genocide in Rwanda" łączy się w tym serwisie z ponad 6300 przekazami [dostęp 29.11.2011].

[4] Liczba dostępnych na YouTube materiałów odnoszących się do frazy „zamachy na World Trade Center" wynosi 290 rekordów, natomiast fraza w języku angielskim „World Trade Center” lączy się w tym serwisie z ponad 150000 przekazów [dostęp 29.11.2011]. [5] Liczba dostępnych na YouTube materiałów odnoszących się do frazy „katastrofa smoleńska” wynosi 2030 rekordów, natomiast fraza w języku angielskim „Smolensk crash” lączy się w tym serwisie z ponad 1840 przekazami [dostęp 29.11.2011]. 
tych przykładów nie służy ich utożsamieniu czy porównaniu, lecz odzwierciedla różnorodność strategii poznawczych użytkowników tego serwisu). Okazuje się również, że wielkie sprawy już dawno stały się treścią doświadczeń potocznych, a dopiero na skutek wykorzystania serwisu YouTube zostały one utrwalone (dotyczy to różnorodności ujęć tego, o czym jest mowa powyżej).

YouTube od czasu do czasu pozwala jednak także i na to, by część przekazów tworzonych przez pojedynczych użytkowników stawała się wielką sprawą. Wielkość wyrażałaby się w tym przypadku co najmniej dużą liczbą wyświetleń na podstronie serwisu, na której został umieszczony konkretny przekaz. Rzecz jasna w tym znaczeniu wielkość implikuje niekiedy tymczasowość. Jednakże wielkość może być również rozumiana jako charakterystyka wypowiedzi, która stanie się ważna w kontekście tematu, do którego będzie się odnosiła.

Jeśli wielką sprawą jest temat miłości, to tę „wielkość” w ujęciu ilościowym potwierdza liczba 5250000 rekordów, które wyświetla serwis YouTube na zadaną frazę „love”. Wśród najbardziej popularnych przekazów podanych przez wyszukiwarkę YouTube znajduje się wideoklip Where Is The Love? nagrany przez zespół The Black Eyed Peas, który był wyświetlony około 48599875 razy. O czym świadczą te duże liczby? Na pewno pokazują one dominujące współcześnie trendy muzyczne, estetyczne, są potwierdzeniem tego, że ogromny wpływ wideoklipu modeluje sposób myślenia o tym, czym jest miłość, jak ją pojmować. Podane liczby świadczą o tym, że skoro jakiś użytkownik umieścił ten przekaz na stronach serwisu, a ponad czterdzieści milionów odbiorców na całym świecie obejrzało go, to znaczy, że przynajmniej ta liczba użytkowników albo stara się i chce myśleć o miłości w sposób zaproponowany przez autorów tego wideoklipu, albo przynajmniej traktuje ten przekaz jako źródło doświadczeń estetycznych. Oczywiście na najogólniejszym poziomie taki wynik popularności wideoklipu potwierdza, że treść tego przekazu może się zwyczajnie komuś podobać.

Internet jest medium codzienności, utrwalającym różnorodne wzorce postaw moralnych. Świadomość liczby odwiedzin na stronach YouTube może pomóc w zrozumieniu, że ten serwis społecznościowy odzwierciedla nie tylko dominujące gusty i trendy kultury, ale także horyzonty etyczne, w odniesieniu do których użytkownicy konstytuują lub utrwalają własną tożsamość. YouTube staje się medium kształtującym moralność pojedynczych użytkowników oraz zbiorowości. Jest w tym wielka szansa, jest również zagrożenie.

Szansą okazuje się to, iż odpowiednie funkcjonowanie tego serwisu może utrwalać społecznie określone wzorce zachowań i postaw moralnych. Kontrola tego zjawiska byłaby błędem systemowym, gdyż siłą tego medium, jak i innych serwisów społecznościowych w Internecie, jest nieustanna oddolna możliwość samoorganizacji i samoprzekształcenia. 
Zagrożeniem jest natomiast przede wszystkim to, iż wiele przekazów i przywoływanych przez nie porządków wartości ulega szybkiemu zapomnieniu, a w licznych przypadkach również zaniknięciu. Niebezpieczeństwem może być także sytuacja, w której YouTube wykorzystane zostanie jako medium wzmacniające zachowania agresywne (myślimy na przykład o uczniach, którzy upokarzają kogoś w „realu”, a następnie umieszczają swój przekaz na stronach serwisu) lub jako środowisko komunikacyjne służące artykułowaniu nienawiści do kogoś innego.

W wielu przypadkach jest tak, że człowiek, który umieszcza w sieci przekaz mówiący o jego własnym cierpieniu, szuka w ten sposób w społeczności internetowej zrozumienia, współczucia, akceptacji[6]. Może się jednak zdarzyć, iż taki użytkownik będzie narażony na kpinę, agresję czy odrzucenie. Każde medium jest ambiwalentne. Wartość moralną potrzebną do oceny czynu tworzy się w sytuacji wykorzystania medium, a więc de facto wtedy, gdy następuje relacja między jednym a drugim człowiekiem poprzez środek przekazu. W tym przypadku środek przekazu jest jedynie protezą bezpośredniej relacji osobowej, tylko tym.

Potoczne mówienie o tym, że media czynią samo zło, jest niebezpieczne moralnie. Media nie mają wolnej woli, nie mogą być też odpowiedzialne za to, co człowiek czyni drugiemu człowiekowi. Media nie są osobami, bytami rozumnymi, a zatem $z$ natury rzeczy nie mogą przejmować odpowiedzialności za to, do czego są wykorzystywane przez ludzi. Przekornie można stwierdzić, że człowiek mówiący, że media powodują zło na świecie, ucieka w ten sposób od odpowiedzialności za treść przekazu (jako autor, twórca czy najogólniej rzecz ujmując - nadawca) oraz za jego odbiór (czytelnik, widz, użytkownik, internauta czy po prostu - odbiorca).

Media wpisujące się w trend Web 2.0, a do tych zaliczamy przecież YouTube[7], wyznaczają nowy horyzont komunikacyjny i etyczny. To właśnie serwisy społecznościowe mogą w przestrzeni relacji społecznych wypełnić gigantyczną przepaść, której podmiotami są nadawcy i odbiorcy mediów komunikacji masowej. Jest to przepaść, w której wieje chłodem depersonalizacji. Wielkie sprawy w życiu jednostek i zbiorowości, które są instrumentalnie, wulgarnie oraz schematycznie przedstawiane $\mathrm{w}$ mediach, dążących do banalizacji podmiotowego świata, przetapiane są na abstrakcyjne dane. Jednakże te sprawy mogą być na powrót czymś za każdym razem niepowtarzalnym, czymś więcej niż tylko pustą kakofonią liczb, porównań, analogii i obrazów, zacierających granice między rzeczywistością a jej przedstawieniami. Wielkie sprawy mogą stać się wyznacznikami osobo-

[6] S. Turkle, Second Self: Computers and the Human Spirit, The MIT Press 2005, s. 189.

\section{W stronę personalizmu}

[7] Por. A. Keen, Kult amatora. Jak internet niszczy kulturę, tłum. M. Bernatowicz, K. Topolska-Ghariani, Warszawa 2007. 
wej relacji między uczestnikami komunikacji. Świat tworzony przez media komunikacji masowej wypacza obrazy człowieczeństwa, kreując przy tym wyobrażenia, których siłą okazuje się przekonanie, iż treść przekazu wypełnia ludzkie doświadczenie egzystencji: myśli, uczuć, pragnień.

Zależności techniczne oraz ekonomiczne przysłaniają relacje osobowe w życiu publicznym, czego skutkiem są niezliczone przekazy medialne uprzedmiotawiające życie i śmierć człowieka. Osoba staje się towarem, a więc towarami stają się w przekazach medialnych także elementy konstytuujące znaczenie tego pojęcia, m.in.: jednostkowość, osobność, intelektualność istoty (w tym: rozumność, odpowiedzialność, wolicjonalność, emocjonalność, intencjonalność), realność, niepowtarzalność, godność. Uprzedmiotowienie osoby ludzkiej oznacza zredukowanie całej doświadczanej rzeczywistości do fatalizmu społeczno-historycznego oraz determinizmu mającego swe podstawy w naturalizmie. Pozornie refleksyjna współczesność stara się wyjaśniać tajemnice człowieczeństwa, odwołując się do biologicznych mechanizmów. Zapomina przy tym, że tak budowana wiedza opiera się na cząstkowych przesłankach, które powodują, że nie jest ona ani ostateczna, ani wystarczająca. Określenie „pozornie” oznacza fragmentaryczność oraz umowność, które zastępują pełnię refleksji. Fatalizm wynika między innymi z tego, że tzw. globalna wioska nie jest, jak chciałby McLuhan, rozszerzeniem naszych zmysłów i naszego poznawania świata, ale paradoksalnie - jego pomniejszeniem. Pojedynczy człowiek odnosi wrażenie, że świat, w którym trwa, nie ma celu, nie ma żadnych trwałych podstaw, że wszystko jest względne i skoro nie można czegoś zmienić w skali makro, to jak można cokolwiek zmienić w skali mikro, po prostu we własnym życiu.

YouTube daje, jak sądzę, możliwość przedstawiania osoby ludzkiej w przekazach medialnych, w sposób uwzględniający jej godność, wolność oraz niepowtarzalność. Serwis ten jest tworzony przez konkretne osoby dla innych osób, a przyczyną tworzenia przekazów nie jest oczekiwany zysk, lecz chęć wyrażenia siebie lub poznania inności znajdującej różne formy wypowiedzi, obok oczywiście realizacji celów czysto ludycznych.

W przekazach komunikacji masowej o strukturze transmisyjnej (monologicznej) osoba ludzka stała się przedmiotem przemysłu kulturowego, towarem, który wykorzystywany jest do cyrkulacji kapitału - totemu współczesności. YouTube jest przywracaniem prawa jednostki do historii modelowanej przez to, co zostaje utrwalone lub wyartykułowane publicznie.

Media komunikacji masowej prowadzą do fatalistycznego pojmowania rzeczywistości doświadczanej przez pojedynczą osobę ludzką: „wszystko już było”, „nic nie można zrobić”, „nikomu nie można zaufać”, „nic się nie liczę”, „nie mam szans”, „inni mają naprawdę dobre życie”, itp. Serwisy społecznościowe, w tym YouTube, pokazują, że może być inaczej, że to symulowane „oni” jest puste, gdy skonfron- 
tuje się je z realnym „ja”. YouTube na poziomie wypowiedzi jest reakcją obronną na powszechny, masowy mechanizm uprzedmiotowienia osoby ludzkiej. To właśnie na skutek uprzedmiotowienia człowieka w przekazach medialnych wzrosło przekonanie o bezcelowości życia, o jego bezsensowności, ale także o tym, że nie ma żadnych trwałych moralnie podstaw, które mogłyby charakteryzować relacje między ludźmi.

Przyczyną takiego stanu rzeczy jest między innymi fakt pojawienia się mediów komunikacji masowej w okresie dynamicznie rozwijającego się kapitalizmu, co doprowadziło do szybkiego ich zawłaszczenia przez potrzebę cyrkulacji kapitału. Media miały zarabiać na siebie, a więc mechanizmy komunikacyjne zostały podporządkowane prawom rynkowym.

Kolejną ważną przyczyną tego, że w mediach komunikacji masowej osoba ludzka szybko zniknęła $\mathrm{z}$ horyzontu przekazu, były niewątpliwie wstrząsy społeczno-etyczne wywołane bolesną dotkliwością totalitaryzmów.

Kapitalizm rozdzielił komunikację masową od etyki, powodując w przypadku przekazów medialnych, że dobro stało się wartością ekonomiczną. Oczywiście, tak sformułowana hipoteza może wywołać sprzeciw. Jednak, myśląc o powyższym stwierdzeniu, warto zastanowić się nad korelacją między treścią przekazów (uwzględniając ich różnorodność gatunkową) a czasem reklamowym, który je wypełnia.

Totalitaryzmy obnażają mechanizm właściwy dla mediów komunikacji masowej, polegający na tym, że treść przekazu jest faktem w momencie jego nadawania, co nie musi być tożsame $\mathrm{z}$ faktem jako elementem rzeczywistości. Treść przekazu wystarczy jako fakt. Ideologia stwarzana $\mathrm{w}$ mediach staje się przecież rzeczywistością, wszak jednym $z$ mechanizmów odkrytych przez badaczy mediów jest mechanizm implozywnego oddziaływania przekazów na odbiorcę. Widz utożsamia treści przekazów z własną wiedzą na temat rzeczywistości. Kapitał oraz ochrona ideologii zniszczyły jakikolwiek, nawet gdyby był możliwy, horyzont personalistyczny w przekazach. Oglądaliśmy i oglądamy fikcję, myśląc, że to rzeczywistość. Takie nastawienie rodzi w nas przekonanie, że to, co nas bezpośrednio nie dotyczy, jest tylko treścią przedstawienia, mniej lub bardziej interesującą narracją. Jako odbiorcy popadamy w ten sposób w obojętność oraz w relatywizm aksjologiczny.

W celu wykorzystania Internetu do przywrócenia w przekazach medialnych każdemu człowiekowi jego niepowtarzalnej, epifanicznej, godnej obecności serwisy społecznościowe umożliwiają przekroczenie ram ekonomicznych oraz ideologicznych. Horyzontem mediów jest osoba ludzka. Autor nie ma na myśli tzw. „personalizacji odbiorcy", polegającej na dedykowaniu poszczególnych programów oraz kanałów tematycznych konkretnym grupom odbiorców, w żargonie ekonomicznym nazywanych „targetem”. Osoba ludzka nie jest 
targetem, tylko „niepowtarzalnym indywiduum o niezbywalnej najwyższej godności [...], nieredukowalnym do żadnych szczególnych jakości ani relacji, za to nadającym wszystkim relacjom, w jakie wchodzi, i jakościom, które rozwija lub których nabywa w trakcie swego istnienia, szczególnej wartości, wreszcie indywiduum, które dla realizacji swoich potrzeb powołuje różne instytucje i formy życia zbiorowego, ale - uczestnicząc w nich - przerasta je i nigdy nie wyczerpuje w ich ramach wszystkich swoich możliwości" [8]. Osoba ludzka przerasta tworzone przez siebie instytucje, o czym zapominają niekiedy osoby ludzkie tworzące media komunikacji masowej oraz osoby, będące odbiorcami tych przekazów.

Treści serwisów społecznościowych kreowane są przez „sieciowe tłumy”, wpływające na „powstanie globalnej emocjonalności”[9]. Web 2.0 tworzy wartość dodaną - nie jest już tylko źródłem danych i informacji, medium mailowej komunikacji oraz narzędziem budowania wirtualnych społeczności. „Stał się czymś o wiele więcej: przestrzenią, w której każdy podłączony do sieci może ulokować swoje zasoby [...] informacji, wiedzy, kultury, emocji, przeżyć, doznań. Każdy też może z tych zasobów czerpać - tego jeszcze w historii nie było" [10]. Serwisy społecznościowe nie muszą służyć wymianie informacji fundamentalnych dla rozwoju nauki czy gospodarki, by mieć istotny wpływ na ewolucję kultury[11].

Tymczasowość, moralność
YouTube jest jednak medium tymczasowości. Coś doraźnie staje się ważne, a więc jest istotne i dostrzegalne w określonym czasie, potem ulega zapomnieniu lub w ogóle znika. Może to być przyczyną nieustannego potwierdzania $\mathrm{w}$ wymiarze społecznym zmienności i płynności obrazów świata w warstwie estetycznej, poznawczej, ale także aksjologicznej.

YouTube pokazuje, jak w sferze komunikacji poważne kwestie etyczne łączą się ze sferą doświadczeń codziennych oraz - jak potoczność staje się dziedziną działań moralnych. Konkretna wypowiedź audiowizualna na stronach tego serwisu wyraża określoną moralność. Porządek wartości przenika się z porządkiem działań komunikacyjnych. Serwis ten odsłania funkcjonowanie potoczności jako ramy modelującej liczne odmiany deontologii.

Jeśli zgodzimy się z tym, co mówi Charles Taylor (abstrahując od kontekstu, w którym powstały cytowane słowa), że „z konieczności musimy orientować się względem dobra, dlatego też nieuchronnie próbujemy określić nasze miejsce w stosunku do niego, a także nadać kierunek naszemu życiu, stąd zaś wynika, że musimy pojmować nasze
[8] A. Stoff, O personalistycznym paradoksie dialogu, w: Dramatyczność i dialogiczność w kulturze, red. A. Krajewska, D. Ulicka, P. Dobrowolski, Poznań 2010, s. 305.

[9] A. Maj, Wikifikacja wiedzy, Travel 2.0 i globalhood, w: Kody McLuhana. Topografia nowych mediów, red. A. Maj, M. Derda-Nowakowski, z udziałem

D. de Kerckhove'a, Katowice 2009, s. 143.

[10] K. Krzysztofek, Wprowadzenie, w: A. Keen, Kult amatora..., s. 11.

[11] A. Maj, op. cit., s. 147. 
życie w formie narracji, jako "poszukiwanie»"[12], to zrozumiemy, że przekazy dostępne w serwisie YouTube są opowieściami, wypowiedziami, które można rozpatrywać w horyzoncie różnych odniesień deontologicznych. Być może wypowiedzi audiowizualne są różnymi formami poszukiwania dobra. Nie jest tak, iż każdy przekaz jest zorientowany etycznie. Jednakże w każdym przekazie - bez względu na to, jaki prezentuje on gatunek i styl - widoczne staje się to, co okazuje się przedmiotem strachu lub drwin, co źródłem nadziei, a co obrazem szeroko pojmowanego dobra. Taylor pisze dalej: „Można by też chyba zacząć od innej strony: ponieważ musimy określać nasze miejsce względem dobra, nie możemy obejść się bez orientacji wobec niego, a zatem musimy postrzegać nasze życie jako opowieść"[13]. Może jest tak, że to z powodu określania naszego miejsca wobec dobra, naszego stosunku do świata wartości, przedstawiamy nasze doświadczenie egzystencji w formie opowieści, której styl i gatunek odzwierciedla naszą wrażliwość, nasz wiek, poziom kompetencji technologicznych oraz sytuację emocjonalną, w której tworzymy przekaz. Ważne jest jednak, iż utrwalony w sieci przekaz zaczyna funkcjonować niezależnie od sytuacji oraz intencji jego autora. Staje się tekstem, który modelowany jest przez mechanizmy komunikacji oraz działania Internetu.

W horyzoncie uwag autora książki Źródła podmiotowości można więc tłumaczyć slogan promujący serwis YouTube „broadcast yourself” nie jako: „nadawaj siebie”, ale jako: „opowiadaj siebie” w znaczeniu: „orientuj się na dobro”. To drugie tłumaczenie ukierunkowane jest na deontologię w wymiarze społecznym oraz na dialog w wymiarze komunikacyjnym. Należy przy tym pamiętać, że wartości są różnie pojmowane, skutkiem czego niełatwe, a często dalekie od koncyliacyjności, stają się rozmowy na stronach serwisu, zarówno te pośrednie (komentarze do wprowadzonych przez nas przekazów w serwisie YouTube oraz liczba wyświetleń zaproponowanej przez nas opowieści), jak i bezpośrednie (wypowiedzi w formie komentarzy, w których użytkownicy Internetu wzajemnie się do siebie odnoszą).

Czym byłyby więc te wielkie sprawy i jak należałoby definiować małe formy? Opowiadanie siebie jest ważne, gdyż jest wprowadzaniem wirtualnego odbiorcy do świata własnych oczekiwań, marzeń, jest proponowaniem własnych gustów estetycznych, jest po prostu przybliżaniem siebie - poprzez to, co intymne i publiczne, poprzez to, co poważne i żartobliwe. Z którejkolwiek strony zaczniemy myśleć o tym, dlaczego YouTube jest medium fenomenalnym oraz moralnie istotnym, musimy pamiętać, że różnorodność użytkowników, języków oraz tworzonych przez nich form narracyjnych odzwierciedla podobne warunki strukturalne ludzkiego bycia, wrażliwości i myślenia.

Pozornie oczywista opozycja między tym, co wielkie, i tym, co małe, nie opiera się na grze językowej, lecz na tym, co w kulturze

[12] Ch. Taylor, Źródła podmiotowości. Narodziny tożsamości nowoczesnej, tłum. M. Gruszczyński,
O. Latek, A. Lipszyc, A. Michalak, A. Rostkowska, M. Rychter, Ł. Sommer, Warszawa 2001, s. 104.

[13] Ibidem. 
współczesnej wynika z indywidualnych, pojedynczych prób mierzenia się z powszechną historią czy ogólnymi problemami społeczno-kulturowymi. YouTube jako serwis społecznościowy jest medium ważnym. O jego znaczeniu decydują użytkownicy i ich style wypowiedzi, bo tak można określić tworzone przez nich przekazy audiowizualne - ich wielość obrazująca odmienne światopoglądy i poziomy kompetencji oraz wrażliwości, a także ich różnorodność gatunkowa i treściowa[14].

Wpływ serwisu jest skutkiem tego, że każda $\mathrm{z}$ wypowiedzi dostępnych i utrwalonych w nim - w postaci przekazu audiowizualnego oraz pisanego (przykładami są materiały odnoszące się do tego, w jaki sposób przedstawia się wydarzenia historyczne czy różne oblicza inności) - jest formą opowieści, małą formą, która może dotyczyć wielkich spraw w życiu pojedynczej osoby lub zbiorowości. Oznacza to, że w opowiadaniu o swoim rozumieniu i pojmowaniu różnorodnych problemów mieści się opowiadanie o sobie, o tożsamości indywidualnego użytkownika, o kulturze, w której on żyje, o otaczającym go społeczeństwie.

Opowieści przybliżają wyobrażenia o wielkich sprawach do doświadczeń codziennych, które konstytuują granice rozumienia, wyobrażania oraz odczuwania świata, który był i który jest. Małe formy są wielkie, dlatego, że niczym alef Borgesa skupiają w sobie złożoność rzeczywistości, będąc jednocześnie za każdym razem osobliwym, pojedynczym kosmosem znaczeń, sensów i wartości.

„For Jonah Mowry. Whats going on?" przykład
Jonah Mowry umieścił na stronach serwisu YouTube krótką opowieść o sobie. Siedząc przed kamerą internetową, płacząc, pokazuje kolejne kartki, na których mówi o swoich doświadczeniach $\mathrm{z}$ innymi ludźmi, opowiada także o tym, że planował samobójstwo. Najprawdopodobniej kartki, na których zapisane są poszczególne zdania, służą wyrażeniu tego, czego sam nie byłby w stanie wyrazić przed kamerą, łzy utrudniałyby mu wysłowienie się. Niezwykle ważnym elementem wypowiedzi jest rama muzyczna, którą stanowi piosenka Breath me w wykonaniu Sia[15].

Wołanie Jonaha obejrzało ponad osiem milionów trzysta tysięcy użytkowników[16]. Przekaz wywołał skrajnie różne reakcje. Wielu użytkowników nagrało swoje odpowiedzi, które pełne są współczucia, emocji, a także opowieści o podobnych przeżyciach. Wielu innych internautów skoncentrowało się na tym, że być może Jonah skłamał, że oszukał środowisko użytkowników sieci. Krytyczne uwagi stały się treścią komentarzy oraz „dowodów” prezentowanych na stronach serwisu YouTube. Co jednak, jeśli Jonah powiedział o sobie prawdę? Jaki musi być jego prywatny świat, w którym agresja i nienawiść innych
[14] P. Levinson, Nowe nowe media, tłum. M. Zawadzka, Kraków 2010, s. 45-47.

[15] Utwór był wykorzystany w serialu telewizji HBO zatytułowanym Sześć stóp pod ziemią oraz w jednym z epizodów serialu Luther (sezon 1, epizod 5).
[16] Dokładnie: 8392921 użytkowników. Por. http://www.youtube.com/watch?v=TdkNn3Ei-Lg [dostęp: 19.12.2011] 
pozostawiają realne ślady na jego ciele oraz powodują u niego nienawiść do samego siebie? Jak to się dzieje, że ludzie nie umieją opowiedzieć o swoich problemach osobom $\mathrm{z}$ najbliższego otoczenia, a potrafią znaleźć swych powierników wśród użytkowników sieci? $\mathrm{Na}$ powyższe pytania można znaleźć odpowiedzi, zanurzając się w opowieść Jonaha (zakładamy przy tym, że jest prawdziwa). Zresztą jej autor pisze, że: „Wszystko ze mną dobrze. Nie wierzcie internetowym plotkom. Do wszystkich moich przyjaciół oraz wspierających mnie osób [wpis pochodzi z 18.12.2011]. Nagrałem to wideo cztery miesiące temu, zanim zaczął się rok szkolny. Miałem 13 lat. To był bardzo mroczny emocjonalnie okres w moim życiu. Nagrałem to wideo o czwartej nad ranem; nie mogłem spać przez całą noc, zbyt wiele złych rzeczy działo się w mojej głowie”. Dalej Jonah pisze, że ostatni rok szkolny, podobnie było również w latach wcześniejszych, był okresem niezwykle trudnym.

Zanim odniesiemy się w pełni do listu adresowanego do osób, które wsparły Jonaha, prześledźmy wprowadzoną przez niego narrację, dla której można wyrożnić trzy plany układające ją w spójny przekaz: warstwę słowną (kartki z zapisanymi słowami), warstwę muzyczną (utwór zatytułowany Breath me) oraz warstwę wizualną (twarz). Okazuje się, że określone zestawienie tych porządków w narracji staje się podstawą głębokiej, osobowej relacji między nieznającymi się użytkownikami sieci. Wobec prawdy o człowieku każdy przekaz staje się możliwym medium wartości. Parafrazując słowa Charlesa Taylora, orientowanie się na dobro powoduje, że naszą sferę wartości łączymy $\mathrm{z}$ indywidualnym doświadczeniem, by w ten sposób zbudować opowieść ważną dla innych osób, w przypadku Internetu - dla użytkowników, o ile będą oni umieli utożsamić się z przedstawionym problemem albo $\mathrm{z}$ autorem przekazu. Interesujące jest w tym kontekście, że podobieństwo między użytkownikiem sieci a Jonahem może się zrodzić na skutek emocji, które wywołuje piosenka stanowiąca ramę audialną dla omawianego wideo.

Kartki. Oto treść słów, które Jonah zapisał na kartkach pokazywanych przez niego przed kamerą w kolejności, która układa się w opowieść o cierpieniu i lęku: „Cześć, jestem Jonah! Wyglądam na osobę szczęśliwą, prawda? No cóż, nie jestem. Wszystko, co widzicie, jest nieprawdziwym mną (ang. is the fake me). Ale jestem prawdziwym Jonahem Mowry. Zrobiłem kilka rzeczy (ang. I've done things ...) - Rzeczy, z których nie jestem dumny. Ciąłem się ... wiele razy. Mam blizny. [w tym miejscu Jonah pokazuje swoje blizny - przyp. M.K.]. Opcją było samobójstwo... wiele razy [napis pokrywa cały kadr dla zaakcentowania wypowiedzi - przyp. M.K.]. Pierwszy raz ciąłem się, gdy byłem w drugiej klasie. Byłem zastraszany każdego dnia... Od pierwszej klasy. A za miesiąc zaczynam ósmą klasę. Nie jestem gotowy... Opuścił mnie bliski przyjaciel. Następne rzeczy zaczęły się dziać później. Jestem przerażony. Ażeby powrócić [tutaj płacze - przyp. M.K.]. Wiele osób mnie nienawidzi. Nie wiem, dlaczego... Ale przy- 
puszczam, że... ponieważ w jakiś sposób ja również siebie nienawidzę. Gej. Fag (oszołom). Dick (kutas). Douche (Natrysk). Homo. Dupek... A lista ciągnie się i ciągnie... Nie mogę tego zrobić więcej!!! Jestem zmęczony tym całkowitym rozdarciem. I tym odbudowywaniem siebie tylko po to, by ZNOWU się rozpaść. [brak tekstu, tylko muzyka i twarz - przyp. M.K.]. Ale... Nigdzie nie idę... Ponieważ jestem silniejszy niż wtedy, gdy... I... Mam milion powodów, by zostać tutaj”[17].

Warstwa muzyczna. Utwór muzyczny, będący ramą audialną dla omawianego przekazu, zaczyna się od słów: „Help, I have done it again/ I have been here many times before/ Hurt myself again today/ And the worst part there's no-one else to blame.... W piosence mowa jest o cierpieniu, o samotności oraz o tym, że kolejny raz ktoś zadaje sobie ból i nie ma przy nim nikogo, kto mógłby ulżyć tej osobie w cierpieniu. Cały utwór brzmi jak wołanie o pomoc. Można przyjąć, że w opowieści Jonaha utwór ten służy pobudzeniu emocji, pełniąc głównie funkcję emotywną, wywołując uczucia nostalgii, smutku, empatii.

Zapewne narracja Jonaha jest odzwierciedleniem wpływu kultury popularnej na sposób mówienia o własnych emocjach. Utwór Brathe me wywołuje szczególny nastrój u autora przekazu, a jednocześnie buduje wspólną przestrzeń doświadczenia podobnych uczuć u odbiorcy. Można przyjąć, że na tym poziomie komunikacji przywołany utwór muzyczny jest czymś w rodzaju szczerego wyznania, jakby kultura popularna budowała pewne „ekwiwalenty” szczerości, której nie trzeba artykułować wprost[18]. Jonah mówi o sobie w sposób, który odpowiada jego wrażliwości, wiekowi, ale także stylom odbioru kultury, w której uczestniczy. Dotyczy to także odbiorców. Może właśnie przebywanie internautów $\mathrm{w}$ niemal identycznej semiosferze powoduje, iż przekaz staje się zrozumiały, a jednocześnie wiarygodny. Przecież kultura popularna nie uniemożliwia zawiązania relacji osobowych. Te są realne, choć kulturowym przemianom ulegają teksty kultury wykorzystywane do ich budowania lub niszczenia. Utwór muzyczny „wypełnia” emocjami relację między użytkownikiem poznającym dramat Jonaha a samym Jonahem. Omawiany przekaz trwa niemal tyle samo minut, co wideoklip do tej piosenki.

Warstwa wizualna. Konstrukcja przekazu opiera się na elementarnych działaniach narracyjnych. Zapewne Jonah ma włączoną webkamerę, która ogranicza jego ruchy, przekaz nie jest zmontowany, a wcześniej zostały przygotowane jedynie wypowiedzi zapisane na kartkach. Odległość Jonaha od kamery buduje niezwykłe wręcz wrażenie, gdyż to twarz Jonaha, zdaniem autora tej interpretacji, wzmacnia relację osobową między użytkownikiem przekazu a jego twórcą.

[17] Autor niniejszego artykułu starał się wiernie oddać w tłumaczeniu treść, którą przekazuje w języku angielskim Jonah Mowry. Por. http://www.youtube. com/watch?v=TdkNn3Ei-Lg [dostęp: 19.12.2011].
W oryginale każde zdanie Jonaha kończy się kropką lub wielokropkiem.

[18] W. J. Burszta, W. Kuligowski, Sequel. Dalsze przygody kultury w globalnym świecie, Warszawa 2005, s. 13. 
Jonah płacze, nie potrafi powstrzymać łez. Przecież „twarz, choć jest jeszcze rzeczą wśród rzeczy, przebija formę, która ją ogranicza. Znaczy to konkretnie, że twarz do mnie mówi, a tym samym zaprasza do relacji, która nie ma wspólnej miary ani z władzą rozkoszowania się, ani z władzą wiedzy" [19]. Ta twarz jest zewnętrznością Jonaha. Łzy, oczy, smutek tworzą kontury, poprzez które staramy się odnieść do tego, co jest prawdą o tym chłopcu, a poprzez prawdę o nim - do tego, co może być prawdą o nas. Jest jeden Jonah i ponad osiem milionów trzysta tysięcy wpisów, a więc twarz broni się przed anonimowością Dotyczy to także samych komentatorów wideo zatytułowanego What's going on. Odnieść można wrażenie, że użytkownik staje twarzą w twarz z osobą cierpiącą, a intymność kontaktu jest wzmocniona przez przekaz muzyczny. Tam, gdzie pojawia się człowiek - tam też zaczyna tworzyć się przestrzeń dramatu. Serwis YouTube jest światem dramatycznych wyznań, których obrazem są łzy.

Kartki, warstwa wizualna oraz warstwa audialna stanowią spójną całość. Ważne jest jednak, że stanowią one formę służącą wyrażeniu dramatu człowieka, który zostaje poniżony przez innych ludzi do tego stopnia, iż odbiera mu to chęć do życia.

Zbyt często myślimy o tym, że problemy nastolatków są problemami „tylko” nastolatków, a nie po prostu zwyczajnych ludzi. Jonah mówi o tym, że się tnie, że wielokrotnie myślał o samobójstwie - ile osób nie miało podobnych myśli, ile osób nie odczuwa trwogi przed innymi ludźmi, ile osób nie odczuwa, że ich egzystencja przepełniona jest bezsensem i cierpieniem. To właśnie twarz i ból Jonaha zobrazowane w tak małej formie narracyjnej dotykają wielkiej sprawy - lęku przed brakiem sensu życia (które może być przerwane bezsensowną śmiercią samobójczą).

W tej krótkiej formie znajduje się wiele treści, które na różnym poziomie wrażliwości dotyczą tych problemów, z którymi boryka się większość ludzi. Liczba wyświetleń omawianego przekazu potwierdza, że użytkownicy YouTube starają się współodczuwać cierpienie Jonaha, a także na miarę własnych możliwości mu pomóc, czego szczególnym przykładem są liczne odpowiedzi zarówno w formie wpisów na forum, jak i w formie przekazów audiowizualnych. „Bądź silny!”, „chciałbym się przyłączyć do tych osób, które wspierają Jonaha. Jonah, mam nadzieję, że wiesz, iż masz moje wsparcie" [20]. Jeszcze inny użytkownik serwisu napisał, że komentarze odnoszące się do wideo Jonaha dzielą się na te pełne wsparcia, uśmiechu i życzliwości oraz na te, które epatują agresją, nienawiścią oraz niechęcią do niego, co wynika zapewne z przekonania, iż apel Jonaha jest niepraw-

[19] E. Levinas, Całość i nieskończoność. Esej o zewnętrzności, tłum. M. Kowalska, tłum. przejrzał J. Migasiński, Warszawa 1998, s. 232.

[20] Jeden z użytkowników serwisu YouTube napisał: „I saw this video, http://youtu.be/TdkNn3Ei-Lg,

\section{Dramat}

from Jonah, then I saw this video, http://youtu.be/ 0s7vrxXHcSg, for Jonah, and I wanted to join the support for Jonah. Jonah, I hope you know you have my support". Por. http://www.youtube.com/watch?v= gm2x7QYjp58\&feature=related [dostęp: 19.12.2011]. 
dziwy[21]. Te dwie perspektywy pokazują problem, który jest charakterystyczny dla tego medium - otóż nigdy nie będziemy mieli pewności, czy dany przekaz jest prawdziwy, czy też nie. Można jedynie domniemywać, m.in. na podstawie jego poetyki, na ile przekaz jest autentycznym wyrazem uczuć i przeżyć, a na ile jest kreacją, fikcją, naiwną formą zwrócenia na siebie czyjejś uwagi czy po prostu zaistnienia w przestrzeni mediów. Bez względu jednak na intencje nadawcy, interesująca jest już sama potrzeba umieszczenia tego typu narracji w sieci. Myślę, w kontekście uwag o personalizmie, że nawet gdyby się okazało, iż Jonah nie opowiedział o sobie prawdy, a tylko się wykreował, to jednak bezwzględnie prawdziwe pozostają reakcje innych użytkowników. Autor tych słów przyjmuje jednak, że wyznanie Jonaha jest szczere.

Relacja osobowa pojawia się tutaj zarówno w przypadku apelu Jonaha, który szuka wsparcia i zrozumienia, jak i w przypadku tych osób, które reagują na wypowiedź tego chłopca. Nawet jeśli są użytkownicy, którzy odnoszą się do przekazu krytycznie, zarzucając fałsz jej autorowi, to przecież czynią tak w trosce o te osoby, dla których takie medium jak YouTube może się stać przestrzenią zastępującą to, czego brak „w realu” - bezpośrednich relacji z drugim człowiekiem.

Niebezpieczeństwem zaś na pewno pozostaje fakt, że nigdy ani Jonah, ani inni ludzie, mówiący w małej formie o wielkich sprawach, nie będą mieli pewności, czy odbiorcy ich tekstów nie staną się prześmiewcami, którzy niszczą nadzieję na jakikolwiek sens wynikający $\mathrm{z}$ relacji osobowej zachodzącej między nimi. Relacja osobowa
i tekst
Powyższe uwagi dotyczące możliwości zbudowania relacji osobowej poprzez YouTube nie zmieniają jednak faktu, iż jest to serwis, z którego korzystają użytkownicy prezentujący odmienne style odbioru. Dla wielu z nich przekaz Jonaha jest tylko przekazem, który można parafrazować, jak każdy inny tekst (audiowizualny) - przenosząc podjętą problematykę na grunt figuratywnego języka, w którym na przykład ironia okazuje się pewną strategią dystansowania się od dramatu opisanego przez autora przekazu What's going on. Nie zmienia to jednak zasady, że mówienie o sobie po to, by pomóc komuś innemu, staje się działaniem moralnym. W relacji osobowej to „ja” zostaje podniesione do innego „ja”, by w ten sposób, być może, móc się przejrzeć w sobie i nabrać dystansu do sytuacji, w której się jest.

Jeden $\mathrm{z}$ użytkowników parafrazuje wideo stworzone przez Jonaha, odpowiadając na jego apel. Jego narracja, opowiedziana na kolejnych zapisanych kartkach, przebiega w następującym porządku:
[21] „It is so ironic I have sat here and watch a few videos some of them with support for Jonah and others showing their disbelief that his story is true. And I notice that the one that has lend the support, are all nice, happy, smile, friendly and ADORABLE kids Yet the one that do not believe Johna's story, they all seems to be nasty, angry, frustrated and even envious of the att. he has gotten In other words they are still BULLYING". Zachowana została oryginalna pisownia wpisu na forum. Por. http://www.youtube.com/ watch?v=gm2x7QYjp58\&feature=related [dostęp: 19.12.2011]. 
„Cześć Jonah! Jestem T. Czyż nie wyglądam na szczęśliwego, prawda? To zajęło mi wiele czasu, ale obecnie mogę powiedzieć, że jestem szczęśliwy. Robiłem wiele rzeczy, z których nie jestem dumny, ale zrobiłem także bardzo dużo rzeczy, z których jestem zadowolony. Nigdy nie byłem «normalny». Nigdy nie byłem «fajnym dzieciakiem». Każdy wiedział, że byłem inny, bałem się tego, że nie pasuję. Czasami starałem się ukryć, kim naprawdę byłem. Wymazywano mnie. Byłem obrażany naprawdę za pomocą niewyszukanych słów i, niestety, one mnie krzywdziły. A ja pozwalałem się im ranić. Ale w szkole średniej zacząłem odnajdywać innych ludzi, ludzi, którzy nie byli zainteresowani «normalnością» i wszyscy zostaliśmy przyjaciółmi, i powoli przestałem się ukrywać. Nigdy więcej wymazywania mnie (ang. No more blank me). Skończyłem szkołę średnią, skończyłem college, jestem teraz na uczelni przygotowującej mnie do zawodu cyrkowca. Tak właśnie fajny ja, prawda? Jestem bardzo silny, prawda? Ale ty jesteś pewnie silniejszy niż ja. Cieszę się, że nie zamierzasz sobie zrobić nic więcej. A ci ludzie, którzy nienawidzą ciebie - nie są warci twojego czasu. Możesz na mnie liczyć" [22].

Nie jest przy tym ważne, czy Jonah zapoznał się z tym komentarzem, wszak każdy inny użytkownik może być „Jonahem”, a więc może potrzebować wsparcia. Wśród ponad ośmiu tysięcy wyświetleń tego przekazu znaleźć można wpisy, których użytkownicy, zapewne znający problem Jonaha, odnoszą się bezpośrednio do autora wyżej zacytowanej wypowiedzi, dziękując mu za to, co zrobił[23]. Zdanie „You've got my support” powraca w wielu innych komentarzach - audiowizualnych oraz pisanych, a więc można liczyć na internautów.

Forma wyznania zaproponowana przez Jonaha wytworzyła nową konwencję mówienia o sobie, w której wykorzystywana jest webkamera, kartki z zapisanymi wypowiedziami oraz - zazwyczaj, choć nie wiadomo, na ile jest to mechanizm trwały - odpowiedni utwór muzyczny, który tworzy ramę audialną przekazu. Wideo Jonaha jest wyznaniem i inne przekazy, będące odpowiedzią na tę narrację, są różnymi typami wypowiedzi, w której upublicznia się to, co intymne. Jednakże każdy przekaz, nawet najbardziej osobisty, staje się tekstem, który podlega prawom zmieniającym jego status i znaczenie. Audiowizualne odpowiedzi na apel Jonaha upodabniają się w swojej poetyce do jego wypowiedzi, gdyż w ten sposób ich autorzy chcieliby powiedzieć: jesteśmy tacy sami jak ty, czujemy to samo, co ty, rozumiemy ciebie i współczujemy tobie, jesteśmy blisko. W takiej interpretacji styl przekazu staje się synonimem etyki, a właściwie tego wszystkiego, co na metapoziomie można wyartykułować, korzystając właśnie z samej poetyki jako obrazu emocji, uczuć, myślenia.

[22] Por. What's going on - for Jonah, http://www. youtube.com/watch? $\mathrm{v}=\mathrm{gm} 2 \mathrm{x} 7 \mathrm{QYjp} 58$ \&feature $=$ related [dostęp: 19.12.2011].
[23] Por. http://www.youtube.com/watch?v= gm2x7QYjp58\&feature=related [dostęp: 19.12.2011]. 
Myślenie potoczne tworzy deontologię, której dziedziną wyrazu jest to, co językowe, wizualne oraz audialne. Za pomocą powszechnie znanych, codziennych formuł - poprzez odpowiednie ich zestawienie - zyskuje się nową jakość komunikacyjną, która z jednej strony jest skonwencjonalizowana (podobne teksty, utwory, kontekst), a z drugiej strony staje się czymś w rodzaju nowej wypowiedzi, której autorem jest użytkownik odczuwający potrzebę zareagowania na apel Jonaha. Ten drugi aspekt jest oryginalny nie tyle ze względu na treść, ani nawet $\mathrm{z}$ powodu umieszczenia $\mathrm{w}$ serwisie własnego komentarza (wszak użytkownicy, a to jest ich siłą oraz słabością, lubią się naśladować - naśladownictwo kreuje społeczności w sieci), ale $\mathrm{z}$ powodu udziału konkretnej, niepowtarzalnej osoby, która pragnie odnieść się do słów innej konkretnej osoby.

\section{Zakończenie}

Większość z nas chciałaby zapewne być po prostu dobra. Wiele osób z tej większości użytkuje Internet. Część z tych osób korzysta z YouTube. Niektórzy zaś mają potrzebę opowiedzenia na różny sposób własnego pragnienia bycia dobrym. Zdarza się, że właśnie w opowieści, w obrazach nas samych zstępujemy z „wyżyn” banału oraz fatalizmu na ulotny grunt czynienia dobra. Małe świadectwa, którymi są nasze wypowiedzi, stają się być może początkiem wyznaczającym nowe formy deontologii, której granice określa potoczność. Przecież Jonah pisze, że ma miliony powodów, by ze sobą nie skończyć, że tymi powodami są wszyscy ludzie, którzy poprzez YouTube (a także Facebook) odpowiedzieli na jego apel. Nawet jego prześladowcy zmienili swoje nastawienie względem niego.

Wielkie sprawy wypowiedziane w małej formie zyskują swoją siłę, ale również po prostu ludzką twarz. Małe formy służą wielkim sprawom w dużej mierze po to, by poprzez medium osoba spotkała się $\mathrm{z}$ drugą osobą. Media są jednak przestrzenią dramatu, w której najgorszą z ról ma do odegrania ten, który chce wszystko zniszczyć. Pragniemy jednak, aby i ten w tej przestrzeni odnalazł dla siebie szlachetniejszą rolę, nawet, jeśli tym kimś jesteśmy my sami.

Pod naszymi stopami jest nasz świat - scena dramatu. Chodzimy po niej, widzimy ją i słyszymy oraz dotykamy jej rękami. Przedstawienia sceny mogą być różne, różne mogą być jej wyobrażenia i teoretyczne koncepcje; jedno będzie jednak się stale powtarzać: scena jest. Powstaje pytanie: jak jest? Na pytanie to odpowiadają różne ontologie świata. Dla Arystotelesa scena jest całością samoistnie bytujących rzeczy - substancji, dla George’a Berkeleya jest wspólnym wyobrażeniem ludzi - snem, który sprawia w ich duszach sam Bóg. Ale dla ludzi zaangażowanych w przeżywanie dramatu scena życia jest przede wszystkim płaszczyzną spotkań i rozstań, jest przestrzenią wolności, w której człowiek szuka sobie domu, chleba, Boga i w której znajduje cmentarz. Scena znajduje się u stóp człowieka[24].

Czasami jednak najłatwiej tę scenę, która znajduje się u stóp człowieka, podeptać palcami.

[24] J. Tischner, Filozofia dramatu. Wprowadzenie,

Kraków 1998, s. 8-9. 